\title{
Transcription Initiation Factor TFIID Subunit 1
}

National Cancer Institute

\section{Source}

National Cancer Institute. Transcription Initiation Factor T FIID Subunit 1. NCI Thesaurus.

Code C17677.

Transcription initiation factor TFIID subunit 1 (1872 aa, $213 \mathrm{kDa}$ ) is encoded by the human TAF1 gene. This protein plays a role in protein phosphorylation, cell cycle progression and RNA polymerase II-mediated transcription. 